\title{
Evaluation of atopy in patients with COPD*
}

Avaliação de atopia em portadores de DPOC

\author{
Margarida Célia Lima Costa Neves, Yuri Costa Sarno Neves, \\ Carlos Mauricio Cardeal Mendes, Monalisa Nobre Bastos, \\ Aquiles Assunção Camelier, Cleriston Farias Queiroz, \\ Bernardo Fonseca Mendoza, Antônio Carlos Moreira Lemos, \\ Argemiro D'Oliveira Junior
}

\begin{abstract}
Objective: To determine the prevalence of atopy and to evaluate clinical, laboratory, and radiological profiles in patients with COPD. Methods: This was a cross-sectional study involving outpatients with stable COPD (defined by the clinical history and a post-bronchodilator $\mathrm{FEV}_{1} / \mathrm{FVC}<70 \%$ of the predicted value). The patients completed a questionnaire regarding clinical characteristics and atopy, after which they underwent nasal lavage cytology, skin prick testing, chest X-rays, arterial blood gas analyses, and determination of total serum lgE. Results: Of the 149 subjects studied, $53(35.6 \%), 49(32.8 \%)$, and $88(59.1 \%)$ presented with nasal eosinophilia, a positive skin prick test result, and symptoms of allergic rhinitis, respectively. Correspondence analysis confirmed these findings, showing two distinct patterns of disease expression: atopy in patients with COPD that was less severe; and no evidence of atopy in those with COPD that was more severe (reduced FEV and hyperinflation). There was a statistically significant association between nasal eosinophilia and a positive bronchodilator response. Conclusions: Using simple and reproducible methods, we were able to show that there is a high frequency of atopy in patients with COPD. Monitoring inflammation in the upper airways can be a useful tool for evaluating respiratory diseases in the elderly and in those with concomitant asthma and COPD, a clinical entity not yet fully understood.
\end{abstract}

Keywords: Pulmonary disease, chronic obstructive; Allergy and immunology; Nasal lavage fluid; Asthma; Rhinitis, allergic, perennial.

\section{Resumo}

Objetivo: Determinar a prevalência de atopia e avaliar o perfil clínico, laboratorial e radiológico de pacientes com DPOC. Métodos: Estudo de corte transversal com pacientes ambulatoriais portadores de DPOC estável (definida pela história clínica e relação $\mathrm{VEF}_{1} / \mathrm{CVF}<70 \%$ do previsto após broncodilatador). Os pacientes responderam um questionário clínico e de atopia e foram submetidos a citologia de lavado nasal, teste cutâneo de alergia, radiografia de tórax, hemogasometria arterial e dosagem de lgE total. Resultados: Dos 149 indivíduos avaliados, $53(35,6 \%), 49(32,8 \%)$ e $88(59,1 \%)$, respectivamente, apresentavam eosinofilia no lavado nasal, teste cutâneo positivo e sintomas de rinite alérgica. A análise de correspondência confirmou esses achados, evidenciando dois perfis distintos de doença: a presença de atopia em pacientes com estágios mais leves de DPOC, e a ausência de características de atopia em pacientes com aspectos de doença mais grave ( $\mathrm{VEF}_{\text {1 }}$ reduzido e hiperinsuflação). Houve uma associação estatisticamente significante entre eosinofilia no lavado nasal e prova farmacodinâmica positiva. Conclusões: Este estudo identificou uma alta frequência de atopia em pacientes com DPOC, utilizando ferramentas simples e reprodutíveis. A monitorização inflamatória de vias aéreas parece ser uma ferramenta útil para avaliar as doenças respiratórias em idosos, assim como em pacientes com sobreposição de asma e DPOC, entidade clínica ainda pouco compreendida.

Descritores: Doença pulmonar obstrutiva crônica; Alergia e imunologia; Líquido da lavagem nasal; Asma; Rinite alérgica perene.

\footnotetext{
* Study carried out in the Department of Pulmonology, Professor Edgard Santos Hospital Complex and under the auspices of the Graduate Program in Medicine and Public Health, Universidade Federal da Bahia - UFBA, Federal University of Bahia - School of Medicine, Salvador, Brazil.

Correspondence to: Antônio Carlos Moreira Lemos. Rua Plínio Moscoso, 486, apto. 302, Jardim Apipema, CEP 40155-192, Salvador, BA, Brasil.

Tel. 5571 3203-2200. E-mail: acmlemos1@gmail.com

Financial support: Cleriston Farias Queiroz is the recipient of a scholarship from the Fundação de Apoio à Pesquisa e Extensão (FAPEX, Foundation for Research and Graduate Education) of the Federal University of Bahia.

Submitted: 20 September 2012. Accepted, after review: 8 May 2013.
} 


\section{Introduction}

A progressive inflammatory disease of the lower airways, COPD is characterized by airflow limitation that is not fully reversible. ${ }^{(1,2)}$ The symptoms result from an abnormal inflammatory response of the lungs to the inhalation of noxious particles or gases and are mainly caused by smoking. It is estimated that $10 \%$ of the world population over 40 years of age have COPD, with a major impact on the quality of life of patients and on health care systems..$^{(1,2)}$ Despite being preventable and treatable, COPD is the fifth leading cause of death worldwide (2.7 million deaths/year) ${ }^{(3,4)}$ and will become the third one by 2020, according to World Health Organization estimates. ${ }^{(1)}$

A heterogeneous and multifactorial disease, COPD results from genetic and environmental factors. ${ }^{(1,4)}$ The classical phenotypes are emphysema and chronic bronchitis, which is often associated with bronchial hyperreactivity (BHR). Inflammation of the bronchial wall is characterized by the presence of neutrophils and macrophages and by increased concentrations of $1 \mathrm{~L}-8$ and Th1 cytokines, as well as by a proteinase/antiproteinase imbalance, and this could explain the poorer response to inhaled corticosteroids (ICs) seen in COPD. ${ }^{(5-7)}$

The association of COPD with asthma and allergic rhinitis (AR), which are diseases characterized by atopy, with Th2 inflammatory response, eosinophilia, and increased $1 \mathrm{~L}-4$ levels, has been discussed. This association is more common in the elderly with late-onset asthma and risk factors for COPD (a post-bronchodilator $\mathrm{FEV}_{1}<70 \%$ of the predicted value, hyperinflation, and smoking). ${ }^{(7)}$ Patients with this profile can present with a positive skin prick test (SPT) result, increased serum lgE levels, bronchial remodeling, and eosinophilic inflammation, similarly to those with asthma. ${ }^{\left({ }^{8-11)}\right.}$ Common to allergic respiratory diseases, BHR has been described as a risk factor for the development of COPD, even without reported asthma. ${ }^{12,13)}$

The association of COPD and atopy, despite current evidence, has been discussed since 1960, with the advent of the "Dutch hypothesis", and has been corroborated by recent studies demonstrating the importance of sputum eosinophilia in patients with COPD and the potential benefits of the use of 1Cs in such patients. The existence of a subgroup of patients with COPD who have a greater bronchodilator response (a positive bronchodilator response), according to the Dutch hypothesis, is due to the fact that asthma, chronic bronchitis, and emphysema have the same genetic basis, are modulated by the environment, and have varying phenotypic expressions (chronic

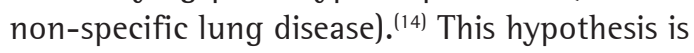
supported by the occurrence of COPD in only $10-15 \%$ of smokers, supposedly more genetically predisposed to developing COPD. ${ }^{(4)}$

The relationship between asthma and COPD appears to be bidirectional and complex. Asthma patients who smoke are known to have more frequent exacerbations, a poorer response to ICs, and early functional impairment, and sometimes it is difficult to distinguish between COPD and severe asthma, the inflammation of which can mimic the neutrophilic inflammation of COPD. ${ }^{(15)}$ Paradoxically, a high frequency of eosinophilic bronchitis has been described in patients with stable COPD. ${ }^{(9)}$ There is evidence of a subgroup of COPD patients who have a greater response to high doses of 1Cs, a positive bronchodilator response, frequent exacerbations, and an $\mathrm{FEV}_{1}$ $<50 \%$ of the predicted value. However, it is necessary to establish the profile of these patients more accurately, reducing the side effects and costs related to the use of high doses of ICs in nonresponding patients. ${ }^{(16)}$

Inflammatory response markers that are useful as indicators for therapy with $\mathrm{ICs}$ in patients with COPD have yet to be established; however, studies have revealed that sputum examination by nasal lavage cytology (NLC) can measure the degree of inflammation in asthma, in COPD, and in other lung diseases both qualitatively and quantitatively, with the advantage of being a simple, inexpensive, and reproducible test. ${ }^{(17,18)}$ There is evidence of eosinophilic bronchitis in up to $17 \%$ of patients with COPD, although the authors of that study did not conclude whether it was associated with a greater response to ICs. (9) There is an association between eosinophilia on NLC and asthma severity in adults, ${ }^{(19)}$ but it is unclear whether this relationship occurs in COPD. This seems important since recent studies have described the overlap between COPD and asthma (overlap syndrome),,$^{(9,11,20)}$ although this association has yet to be further investigated, as well as requiring a clinical and laboratory approach, in order to establish the profile of COPD patients with evidence of atopy. 
The Dutch hypothesis suggests that atopy and BHR, which are important markers of asthma, can be involved in the pathogenesis of COPD, although there is no clear evidence regarding the frequency of atopy (including asthma), AR, eczema, or increased lgE levels in patients with COPD, because most studies have involved small samples and limited evaluation of atopy, usually using only SPTs and not evaluating clinical parameters. In addition, the profile of disease severity in these COPD patients with evidence of atopy is unknown. The objective of the present study was to determine the prevalence of atopy in patients with COPD, as well as to establish their clinical, laboratory, and radiological profiles.

\section{Methods}

This was a cross-sectional study aimed at estimating the frequency of atopy in outpatients with COPD who were followed in the Department of Pulmonology of the Federal University of Bahia Professor Edgard Santos University Hospital, located in the city of Salvador, Brazil. Patients who were admitted to the outpatient clinic with a diagnosis of stable COPD (any stage) between November of 2008 and March of 2011 and who gave written informed consent were consecutively included in the study. The diagnosis of COPD was defined by clinical history (dyspnea, chronic cough, sputum, pulmonary exposure to noxious particles or gases) and by spirometry (a post-bronchodilator $\mathrm{FEV}_{1} / \mathrm{FVC}<70 \%$ of the predicted value). ${ }^{(1)}$ We excluded patients who had respiratory tract infection in the previous month, who used nasal or systemic corticosteroids in that period, or who used antihistamines in the previous week. We also excluded patients with chest X-ray findings of parenchymal lesions not consistent with COPD. The study was approved by the local research ethics committee.

The patients underwent thorough history taking and a complete physical examination, with an emphasis on the clinical parameters of COPD and atopy and on the history of comorbidities. We used the quality of life questionnaire known as Airway Questionnaire 20(AQ20), which has been validated for use in Brazil. ${ }^{(21)} A$ case definition of AR was established by the presence of nasal symptoms triggered by aeroallergens (at least two of the following: rhinorrhea; sneezing fits; congestion, or nasal itching). ${ }^{(2)}$ The patients underwent SPTs, spirometry, determination of serum $\operatorname{lgE}$, arterial blood gas analyses, chest X-rays, and stool examination for parasites. All tests were required during a single visit and were performed at the aforementioned hospital by trained staff within two months after the initial evaluation of each patient.

All SPTs were performed with material from the US Food and Drug Administration, using antigens from Aspergillus fumigatus, Blomia tropicalis, Dermatophagoides pteronyssinus, cat and dog dander, house dust, and histamine. A positive test result was defined as the presence of papules $>3 \mathrm{~mm}$ in diameter to at least one antigen. For NLC, eosinophilia was defined as an eosinophil count $\geq 5 \%$, whereas neutrophilia was defined as a neutrophil count $\geq 5 \%$. Infectious vasomotor rhinitis was defined as a cell count $>1,000,000$ cells. In addition, the presence of bacteria and fungi was assessed.

The parameters measured by spirometry included $\mathrm{FEV}_{1}$, the $\mathrm{FEV}_{1} / \mathrm{FVC}$ ratio, and response to a short-acting bronchodilator (albuterol challenge), expressed as the difference between pre- and post-bronchodilator FEV ${ }_{1}$ divided by the predicted value for $\mathrm{FEV}_{1}$. A positive challenge response was defined as a ratio $\geq 7 \%$. Arterial blood samples were collected for blood gas analysis, with the patients breathing spontaneously on room air. Serum $\lg E$ levels were measured by ELISA. Posteroanterior and lateral chest X-rays were requested for evaluation of hyperinflation, defined as an increased anteroposterior chest diameter, increased retrosternal air space, a reduced/compressed cardiac silhouette, the presence of bullae, vascular attenuation, and flattening of the hemidiaphragms. ${ }^{(23)}$ Three stool samples were requested from each patient for stool examination for parasites, including testing for Strongyloides stercoralis by the Baermann method, in order to rule out parasitic eosinophilia.

The patients were divided into two groups: atopic group (those with a positive SPT result and/or AR symptoms accompanied by eosinophilia on NLC) and non-atopic group (the remaining patients, who did not meet any of the previous criteria).

We used the Statistical Package for the Social Sciences, version 11.0 (SPSS Inc., Chicago, IL, USA). Proportions were compared with the chi-square test or Fisher's exact test. The Mann-Whitney test for independent samples was used to compare the distribution of quantitative variables between 
the two groups studied. Multivariate logistic regression analysis was performed to obtain adjusted ORs (the $\mathrm{Z}$ approximation), and 95\% $\mathrm{Cls}$ were calculated. For all analyses, the level of significance was set at 5\%.

Multiple correspondence analysis (classification technique) was performed to obtain the final model, which was configured on a Cartesian grid with four quadrants, each representing a profile of patients. Each point in the model represents one category of variables, and a closer proximity between points in the same quadrant translates into a higher affinity between the corresponding variables in the sample.

\section{Results}

We evaluated 149 patients. The general characteristics of the sample are presented in Table 1. Eight patients were receiving supplemental oxygen via nasal cannula, at a flow of 1-2 L/

Table 1 - Demographic, clinical, radiological, spirometric, and laboratory characteristics of the study sample ( $\mathrm{n}=149)^{\mathrm{a}}$

\begin{tabular}{|c|c|}
\hline Variable & Result \\
\hline Male gender & $104(70.0)$ \\
\hline Age, years ${ }^{b}$ & $70.3 \pm 8.5$ \\
\hline \multicolumn{2}{|l|}{ COPD stage } \\
\hline 1 & $1(0.7)$ \\
\hline 11 & $37(24.8)$ \\
\hline 111 & $100(67.1)$ \\
\hline IV & $11(7.4)$ \\
\hline \multicolumn{2}{|l|}{ MRC dyspnea scale } \\
\hline 1 & $8(5.4)$ \\
\hline 2 & $23(15.4)$ \\
\hline 3 & $42(28.2)$ \\
\hline 4 & 34 (22.8) \\
\hline 5 & $42(28.2)$ \\
\hline Hyperinflation & $130(87.2)$ \\
\hline Positive skin prick test result & $49(32.9)$ \\
\hline Childhood asthma & $6(4.0)$ \\
\hline Heart disease & $30(20.1)$ \\
\hline Diabetes mellitus & $26(17.5)$ \\
\hline Helminthiasis & $12(8.1)$ \\
\hline $\mathrm{FEV}_{1}, \mathrm{~L} / \mathrm{min}^{\mathrm{b}}$ & $1.25 \pm 0.6(0.36-3.56)$ \\
\hline $\mathrm{FEV}_{1}, \%$ of predicted ${ }^{\mathrm{b}}$ & $50.6 \pm 20.7$ (16.0-110.0) \\
\hline $\mathrm{SaO}_{2}, \%{ }^{\mathrm{b}}$ & $93.5 \pm 3.7(74.0-99.0)$ \\
\hline $\mathrm{PaO}_{2}, \mathrm{mmHg}^{\mathrm{b}}$ & $76.8 \pm 10.9(46.0-100.0)$ \\
\hline $\mathrm{PaCO}_{2}, \mathrm{mmHg}^{\mathrm{b}}$ & $42.3 \pm 6.2(28.0-63.0)$ \\
\hline Total serum lgE, b & $523.6 \pm 728.2(1.5-4392.0)$ \\
\hline
\end{tabular}

min, at the time of arterial blood gas analysis and were therefore excluded from it.

Regarding the division of patients into groups, $62(41.6 \%)$ showed evidence of atopy, whereas 87 (58.4\%) did not have a positive SPT result or AR symptoms accompanied by eosinophilia on NLC. Among the patients in the atopic group, $49(79.0 \%)$ had a positive SPT result, 38 (61.3\%) had AR symptoms with eosinophilia on NLC, and 25 (40.3\%) presented with both parameters. The differences between the groups studied are shown in Table 2.

When eosinophilia on NLC and the other study variables were compared, some of the associations found were statistically significant, as shown in Table 3.

Table 4 presents the result of the logistic model with multiple variables, showing adjusted $\mathrm{OR}$ values. There were risk relationships between several independent variables and eosinophilia on NLC (dependent variable of the model). Eosinophilia on NLC was found to be positively associated with a positive SPT result and vasomotor rhinitis, the association being statistically significant. The variables Medical Research Council (MRC) dyspnea scale score and smoking history correlated negatively with eosinophilia, but these associations did not achieve statistical significance. Gender and hyperinflation showed a weak association with the dependent variable of the model (OR values close to 1).

Figure 1 shows the multiple correspondence analysis results. The characteristics are found to be distributed into two distinct profiles of patientsone group of patients with variables indicating less severe COPD and with evidence of atopy, such as eosinophilia on NLC, a positive SPT result, and AR symptoms (left lower quadrant of the graph), and one group without evidence of atopy but with indicators of more severe COPD (i.e., MRC scale scores $\geq 4$, reduced $\mathrm{FEV}_{1}$, hyperinflation, hypercapnia, longer hospital stays, and a long smoking history) and with a higher proportion of female patients (upper right quadrant).

\section{Discussion}

The results of the present study show a high frequency of patients with evidence of atopy, considering SPT results and AR symptoms accompanied by nasal eosinophilia: $41.6 \%$ of the patients studied, a value that is higher than that reported in a previous study, which found 
Table 2 - Clinical, laboratory, and radiological characteristics of the COPD patients studied, by group (atopic vs. non-atopic). ${ }^{a}$

\begin{tabular}{|c|c|c|c|}
\hline \multirow[t]{2}{*}{ Variable } & \multicolumn{2}{|c|}{ Group } & \multirow[t]{2}{*}{$p$} \\
\hline & Atopic & Non-atopic & \\
\hline & $(n=62)$ & $(n=87)$ & \\
\hline Age, years & $65.7 \pm 8.5$ & $69.7 \pm 8.4$ & $<0.01$ \\
\hline Male gender ${ }^{b}$ & $48(77.4)$ & $56(64.4)$ & 0.09 \\
\hline Height, m & $1.63 \pm 0.1$ & $1.62 \pm 0.1$ & 0.25 \\
\hline Weight, kg & $67.5 \pm 14.5$ & $61.6 \pm 13.2$ & 0.01 \\
\hline $\mathrm{FEV}_{1}, \mathrm{~L} / \mathrm{min}$ & $1.4 \pm 0.6$ & $1.2 \pm 0.6$ & 0.03 \\
\hline $\mathrm{FEV}_{1}, \%$ of predicted & $52.8 \pm 21.7$ & $49.6 \pm 20.1$ & 0.48 \\
\hline COPD stage ${ }^{b}$ & & & 0.65 \\
\hline 1 and 11 & $17(27.4)$ & $21(24.1)$ & \\
\hline 111 and IV & 45 (72.6) & $66(75.9)$ & \\
\hline Exacerbations/year & $4.7 \pm 3.5$ & $5.8 \pm 4.9$ & 0.17 \\
\hline Hospital admissions/year & $1.5 \pm 1.6$ & $1.8 \pm 1.5$ & 0.17 \\
\hline Length of hospital stay, days & $10.7 \pm 14.0$ & $17.5 \pm 26.7$ & 0.20 \\
\hline AQ20 questionnaire, \% & $57.1 \pm 24.8$ & $60.3 \pm 24.2$ & 0.44 \\
\hline Smoking history, pack-years & $44.1 \pm 18.1$ & $47.3 \pm 18.6$ & 0.24 \\
\hline Positive bronchodilator response $\mathrm{e}^{\mathrm{b}}$ & $26(42.6)$ & $22(25.3)$ & 0.03 \\
\hline Hyperinflation ${ }^{\mathrm{b}}$ & $51(82.3)$ & $79(90.8)$ & 0.12 \\
\hline $\mathrm{SaO}_{2}, \%$ & $93.7 \pm 3.8$ & $93.4 \pm 3.6$ & 0.59 \\
\hline $\mathrm{PaO}_{2}, \mathrm{mmHg}$ & $78.7 \pm 10.0$ & $75.5 \pm 11.4$ & 0.19 \\
\hline $\mathrm{PaCO}_{2}, \mathrm{mmHg}$ & $41.7 \pm 6.3$ & $42.8 \pm 6.2$ & 0.53 \\
\hline Asthma $^{\mathrm{b}}$ & $4(6.5)$ & $2(2.3)$ & 0.20 \\
\hline \multicolumn{4}{|l|}{ Nasal lavage fluid characteristics ${ }^{\mathrm{b}}$} \\
\hline Eosinophilia & $47(75.8)$ & $6(6.9)$ & $<0.001$ \\
\hline Neutrophilia & $22(35.5)$ & $28(32.2)$ & 0.67 \\
\hline Bacteria & $18(29.0)$ & $22(25.3)$ & 0.61 \\
\hline Vasomotor rhinitis & $16(25.8)$ & $22(25.3)$ & 0.94 \\
\hline Fungi & 7 (11.3) & $4(4.6)$ & 0.12 \\
\hline
\end{tabular}

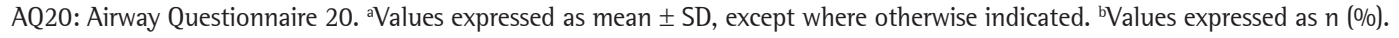

Table 3 - Variables showing statistically significant differences $(p<0.05)$ between the patients with and without eosinophilia on nasal lavage fluid cytology. ${ }^{a}$

\begin{tabular}{|c|c|c|c|}
\hline \multirow[t]{2}{*}{ Variable } & \multicolumn{2}{|c|}{ Eosinophilia on NLC } & \multirow[t]{2}{*}{$\mathrm{p}$} \\
\hline & Yes & No & \\
\hline & $(n=53)$ & $(n=96)$ & \\
\hline $\mathrm{FEV}_{1}, \mathrm{~L} / \mathrm{min}$ & $1.5 \pm 0.5$ & $1.1 \pm 0.6$ & $<0.01$ \\
\hline $\mathrm{FEV}_{1}, \%$ of predicted & $55.3 \pm 22.2$ & $48.0 \pm 19.5$ & 0.04 \\
\hline Positive bronchodilator response $\mathrm{e}^{\mathrm{b}}$ & $24(45.3)$ & 24 (25.3) & 0.01 \\
\hline Symptoms of allergic rhinitis ${ }^{b}$ & $38(71.7)$ & $50(52.1)$ & 0.02 \\
\hline Bacteria on $\mathrm{NLC}^{\mathrm{b}}$ & $20(37.7)$ & $20(20.8)$ & 0.03 \\
\hline Vasomotor rhinitis on $\mathrm{NLC}^{\mathrm{b}}$ & $19(35.8)$ & $4(19.8)$ & 0.03 \\
\hline Fungi on $\mathrm{NLC}^{\mathrm{b}}$ & $7(13.2)$ & $4(4.2)$ & 0.04 \\
\hline
\end{tabular}

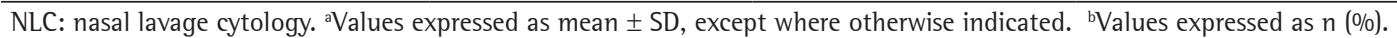

$17 \%$ of cases of atopy among patients with COPD. ${ }^{(9)}$ Although studies have estimated that the worldwide prevalence of AR in adults is 10\%, ${ }^{(22)}$ in specific subgroups of patients, such as patients with COPD, the rate has yet to be determined.
In the present study, 88 patients $(59.1 \%$ of the sample) had AR symptoms triggered by allergens, a frequency that is much higher than the world average. ${ }^{(22)}$ However, the fact that the diagnosis of AR is determined on the basis of information 
Table 4 - Logistic model with multiple independent variables in relation to the presence of eosinophilia on nasal lavage fluid cytology.

\begin{tabular}{lc}
\hline \multicolumn{1}{c}{ Independent variable } & OR (95\% Cl) \\
\hline Positive skin prick test result & $11.2(4.72-28.72)$ \\
Male gender & $1.1(0.43-2.98)$ \\
Hyperinflation & $1.2(0.33-4.77)$ \\
Vasomotor rhinitis & $4.1(1.59-11.39)$ \\
Symptoms of allergic rhinitis & $2.4(0.97-6.17)$ \\
MRC scale score $>3$ & $0.5(0.18-1.45)$ \\
Smoking history $\geq 20$ pack-year & $0.6(0.14-2.23)$ \\
Length of hospital stay > 1 day & $0.6(0.26-1.57)$ \\
\hline MRC: Medical Research Council. Area under the curve $=$ \\
158; pseudo R $^{2}=49.9 \%$.
\end{tabular}

provided by the patient, although this is the recommendation in major consensus guidelines for rhinitis, ${ }^{(22)}$ represents a limitation of the study. In addition, one cannot state that it is in fact rhinitis of allergic etiology. Therefore, we sought to associate this finding from history taking with the laboratory finding of eosinophilia on NLC in order to increase the specificity of the criterion for defining the disease (AR).

One group of authors concluded that only half of the cases of rhinitis have an allergic etiology, the remaining cases being classified as nonallergic rhinitis, without systemic manifestations of atopy

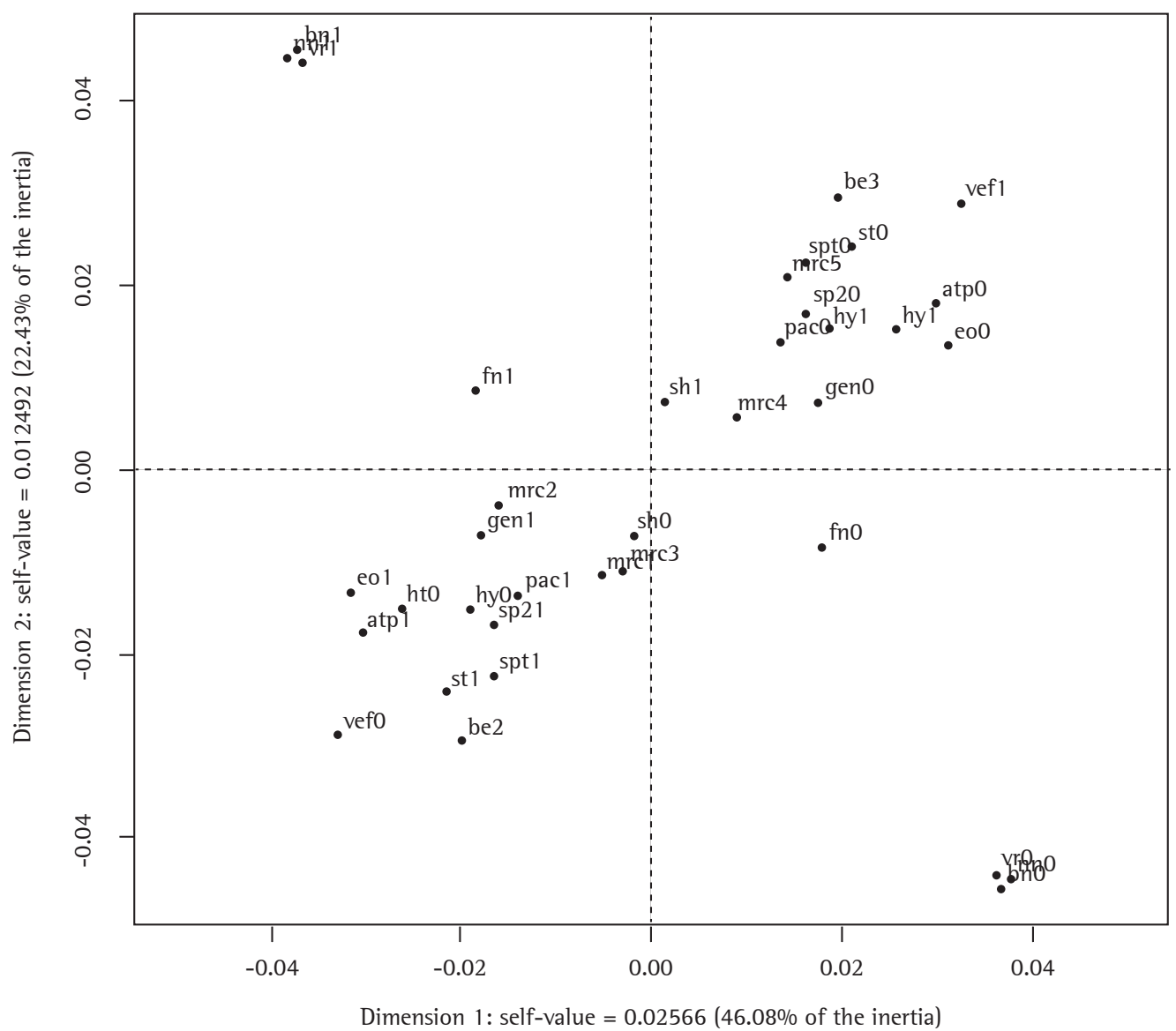

Figure 1 - Correspondence analysis of multiple variables. gen0: female gender; gen 1: male gender; fev0: $\mathrm{FEV}_{1} \geq 1 \mathrm{~L} / \mathrm{min}$; fev1: FEV $<1 \mathrm{~L} / \mathrm{min}$; pac0: $\mathrm{PaCO}_{2}>46 \mathrm{mmHg} ;$ pac1: $\mathrm{PaCO}_{2} \leq 46$ mmHg; sp20: $\mathrm{SpO}_{2}>$ 90\%; sp21: $\mathrm{SpO}_{2} \leq 90 \%$; mrc1: Medical Research Council (MRC) dyspnea scale = 1; mrc2: MRC dyspnea scale $=2 ;$ mrc3: MRC dyspnea scale $=3 ;$ mrc4: MRC dyspnea scale $=4 ;$ mrc5: MRC dyspnea scale $=5 ;$ hy0: no hyperinflation; hy1: hyperinflation; sh0: smoking history $<20$ pack-years; sh 1: smoking history $\geq 20$ pack-years; spt0: negative skin prick test (SPT) result; spt1: positive SPT result; rs0: no allergic rhinitis (AR) symptoms ; rs1: AR symptoms; eo0: no eosinophilia on nasal lavage cytology (NLC); eo 1: eosinophilia on NLC; atp0: eosinophilia on NLC and no symptoms of AR; atp1: eosinophilia on NLC and/or symptoms of AR; vrO: no vasomotor rhinitis on NLC; vr1: vasomotor rhinitis on NLC; fn0: no fungi on NLC; fn 1: fungi on NLC; ht0: length of hospital stay < 1 day; ht 1: length of hospital stay > 1 day; be2: blood eosinophilia; be3: blood eosinophilia. 
(as determined by SPTs or testing for serum $\lg$ E specific to environmental allergens). ${ }^{(24)}$ In contrast, other authors have described an entity designated local AR, which seems to account for $25 \%$ of the total number of patients with rhinitis in allergy clinics and $40 \%$ of patients previously diagnosed with nonallergic rhinitis. ${ }^{(25)}$ Local AR is characterized by an inflammatory response limited to the nasal mucosa, with local production of specific $\lg$, in the absence of systemic atopy. However, locally, there is inflammation, involving eosinophil degranulation, positive responses to nasal challenge with allergens, and a local Th2 immune response. This entity has been found to be associated with ocular symptoms, childhood onset of symptoms (in approximately 40\% of cases), and bronchial asthma. ${ }^{(25)}$ Therefore, these data support the fact that, in our study, subjects with allergen-induced nasal symptoms and eosinophilia on NLC, even without a positive SPT result or increased specific lgE levels, were included in the group of patients with evidence of atopy and those with symptoms but no nasal eosinophilia were removed from this group. The resulting number of patients was still much larger than the populations statistics (38 patients had symptoms accompanied by nasal eosinophilia, and this is equivalent to $25.5 \%$ of our sample). These data underscore the association between COPD and atopy, which has been described since $1960 .{ }^{(14)}$

Atopy, a condition that has an increasing prevalence worldwide and remains little studies in many countries, is associated with worsening of quality of life. In Brazil, data have been collected for the International Study of Asthma and Allergies in Childhood, a population survey assessing the prevalence of allergy in children and adolescents. Disease prevalence was found to be $25.7 \%$ in Brazilian schoolchildren and 29.6\% in Brazilian adolescents, on the basis of the clinical criterion (symptoms) of disease status. ${ }^{(22,26)}$ However, the clinical impact of AR and atopy on patients with COPD, especially in terms of quality of life, has yet to be clearly defined. In the present study, there was no significant difference in quality of life, as assessed by the AQ20 questionnaire, between subjects with and without atopy.

Bivariate analysis comparing the groups revealed that atopic patients showed evidence of more severe COPD (less reduction in absolute FEV ) $_{1}$ and greater reversibility of airflow obstruction, as measured by bronchodilator response ( $p$ $=0.03$ ). Although they were not statistically significant, differences were found in the frequency of exacerbations, length of hospital stay, hyperinflation, and $\mathrm{PaO}_{2}$, suggesting less disease severity among atopic individuals, which is in contrast to previous findings. ${ }^{(16)}$ It is possible that these observed trends could have reached statistical significance if the sample size (and, consequently, the power of the study) were larger.

The difference found between absolute FEV, values $(\mathrm{L} / \mathrm{min})$, which were significantly higher in the atopic group, and the absence of this difference when percentage values were compared can be explained, at least in part, by the fact that this group comprised patients who were younger (a 4-year difference, on average, in relation to non-atopic patients) and heavier (approximately a 6-kg difference, on average). These data could affect the absolute values of this spirometric parameter but not its relationship with the predicted values.

In order to evaluate the influence of upper airway inflammation on the clinical, spirometric, and laboratory characteristics of COPD, we analyzed the variable eosinophilia on NLC and its relationship with the other study variables. Eosinophilia was found to be significantly associated both with higher absolute and higher percentage FEV , values. These results suggest that this inflammatory marker is more strongly associated with less severe COPD (less impaired pulmonary function) than is the SPT.

In addition, there was a higher frequency of AR symptoms and other NLC findings in patients with nasal eosinophilia, which indicates agreement between symptoms and laboratory findings in nasal lavage fluid. The fact that patients with nasal eosinophilia had greater bronchodilator response can be explained by the type of airway inflammation and its association with reversibility of airflow obstruction. ${ }^{(16)}$ This finding is consistent with those of previous studies. ${ }^{(27)}$

Logistic regression analysis confirmed the inverse relationship between atopy and severity of COPD in the study sample-there was an inverse relationship of eosinophilia on NLC with higher MRC scale scores, smoking history, and length of hospital stay. In contrast, a positive SPT result and vasomotor rhinitis correlated positively with nasal eosinophilia, which shows the agreement between these two atopy parameters studied (of 
which one is local and one is systemic) and, at the same time, the relationship between two NLC findings suggestive of upper airway inflammation. Correspondence analysis confirmed the results of the previous analyses by graphically defining the profile of patients with evidence of atopy and less severe COPD and of those with no evidence of atopy and more severe COPD.

Unpublished data from a multicenter study involving latin American cities have shown that $13.2 \%$ of patients with COPD have a combined pattern of asthma and COPD (overlap). This finding can contribute to the development of strategies for the therapeutic management of COPD. ${ }^{(12,13,28)}$ However, only $4 \%$ of the patients studied reported a concomitant diagnosis. This can suggest a local characteristic of the patients in the present study, although the sample was similar to that described in the literature in terms of gender, age, severity, pulmonary function, hyperinflation, and smoking history. ${ }^{(1)}$

Many authors have evaluated markers to identify patients with COPD and atopy (atopic phenotype of COPD), who seem to show a better response to $1 \mathrm{Cs} .{ }^{(12,16)}$ One group of authors suggested that a definition of COPD on the basis of phenotypic characteristics, instead of the current definition, which is based on severity, be used to define treatment strategies. ${ }^{(28)}$ In addition, there have been reports of side effects of ICs in elderly patients, who are often taking several medications, as well as of the high costs of large-scale use of this treatment approach. ${ }^{(16)}$ Major consensus guidelines for COPD recommend the use of $1 \mathrm{Cs}$ in patients with an $\mathrm{FEV}_{1}<50 \%$ of predicted or with frequent exacerbations of COPD. ${ }^{(1,2)}$

Preliminary analyses at our facility revealed that more than $80 \%$ of patients used ICs (data not shown). The use of these drugs was not based on bronchodilator response or on evidence of atopy but rather on pulmonary function deterioration (FRV $_{1}<50 \%$ of predicted) and on the occurrence of frequent exacerbations. There seems to be no difference between the study groups in terms of the use of ICs; therefore, it is unlikely that these drugs could have affected, to some extent, the results obtained. The use of ICs by nearly all patients puts them on a similar footing for evaluation. In addition, the systemic effects associated with ICs are small, compared with those of systemic corticosteroids (excluded from the study), and the influence of these effects on NLC have not been described. Furthermore, the influence of the use of ICs on the study population would be that it would underestimate the finding of an increased prevalence of evidence of atopy, and not the other way around.

The presence of fungi on NLC in 11 patients (7.4\%) who were not taking concomitant ICs is relevant because these are uncommon agents, the progression of which has yet to be fully elucidated. ${ }^{(29)}$ There is evidence of fungal sinusitis increases due to previous antibiotic therapy, use of 1Cs and systemic corticosteroids, and immunosuppression, these microorganisms being associated with greater severity and the need for surgical treatment. ${ }^{(29)}$ With the exception of the use of ICs, none of these risk factors were found in the study population. This underscores the importance of monitoring the upper airways in COPD, even in immunocompetent subjects who are not taking risky medications.

In the present study, we chose NLC over induced sputum cytology, which is associated with complications, especially in the presence of impaired pulmonary function. The NLC technique, which is inexpensive and easy to perform, ${ }^{(17)}$ was used by one group of authors who described the association between asthma severity and the degree of upper airway inflammation. ${ }^{(19)}$ Inhaled nitric oxide, which is a marker of airway eosinophilia, was not used because of its cost and its lower reproducibility. ${ }^{(30)}$ The fact that total $\lg$ E varied widely in the present study, although the mean total $\lg$ E was much higher than normal, and that it has low specificity in diagnosing atopy explained the exclusion of this variable from the study analyses. Determination of specific $\lg \mathrm{E}$ was not used because of its high cost.

Compared with previous studies evaluating atopy and COPD, the present study differs in sample size and in that it used several variables to establish evidence of atopy, previously determined only on the basis of positive SPT results and increased serum $\lg$ E levels. ${ }^{(29)}$ Our results, together with those of future studies, may inform individualized treatment with the use of 1Cs in the subgroup of COPD patients with evidence of atopy.

\section{Acknowledgments}

We would first like to thank the patients, who made the study possible. We would also like to thank the staff of the cytology and clinical analysis laboratory and the spirometry technicians, 
as well as the facility receptionists and everyone who contributed in some way to the present study becoming a reality.

\section{References}

1. Global Initiative for Chronic Obstructive Lung Disease [homepage on the Internet]. Bethesda: Global Initiative for Chronic Obstructive Lung Disease. [cited 2012 Jan 20]. Global strategy for the diagnosis, management and prevention of chronic obstructive pulmonary disease. [Adobe Acrobat document, 90p.]. Available from: http://www.goldcopd.org/uploads/users/files/ G0LD_Report_2011Dec30.pdf

2. Sociedade Brasileira de Pneumologia e Tisiologia. 11 Consenso sobre Doença Pulmonar Obstrutiva Crônica - DPOC. J Bras Pneumol. 2004;30(Suppl 5):S1-S42.

3. Buist AS, McBurnie MA, Vollmer WM, Gillespie S, Burney $P$, Mannino DM, et al. International variation in the prevalence of COPD (the BOLD Study): a populationbased prevalence study. Lancet. 2007;370(9589):741-50. http://dx.doi.org/10.1016/S0140-6736(07)61377-4

4. Eisner MD, Anthonisen N, Coultas D, Kuenzli N, PerezPadilla R, Postma D, et al. An official American Thoracic Society public policy statement: Novel risk factors and the global burden of chronic obstructive pulmonary disease. Am J Respir Crit Care Med. 2010;182(5):693718. http://dx.doi.org/10.1164/rccm.200811-1757ST PMid:20802169

5. Saetta M, Turato G, Facchini FM, Corbino L, Lucchini RE, Casoni G, et al. Inflammatory cells in the bronchial glands of smokers with chronic bronchitis. Am J Respir Crit Care Med. 1997;156(5):1633-9. http://dx.doi.org/10.1164/ ajrccm.156.5.9701081 PMid:9372687

6. Park SW, Lee YM, Jang AS, Lee JH, Hwangbo Y, Kim DJ, et al. Development of chronic airway obstruction in patients with eosinophilic bronchitis: a prospective follow-up study. Chest. 2004;125(6):1998-2004. http:// dx.doi.org/10.1378/chest.125.6.1998 PMid:15189914

7. Barnes PJ. Against the Dutch hypothesis: asthma and chronic obstructive pulmonary disease are distinct diseases. Am J Respir Crit Care Med. 2006;174(3):240-3; discussion 243-4. http://dx.doi.org/10.1164/rccm.2604008 PMid:16864717

8. Soriano JB, Davis KJ, Coleman B, Visick G, Mannino D, Pride NB. The proportional Venn diagram of obstructive lung disease: two approximations from the United States and the United Kingdom. Chest. 2003;124(2):474-81. http://dx.doi.org/10.1378/chest.124.2.474 PMid:12907531

9. Alfaro TM, Freitas Sda S, Cordeiro CR. Overlap between asthma and COPD. J Bras Pneumol. 2012;38(6):813-6. http://dx.doi.org/10.1590/S1806-37132012000600021 PMid:23288131

10. Zeki AA, Schivo M, Chan A, Albertson TE, Louie S. The Asthma-COPD Overlap Syndrome: A Common Clinical Problem in the Elderly. J Allergy (Cairo). 2011;2011:861926.

11. Chang J, Mosenifar Z. Differentiating COPD from asthma in clinical practice. J Intensive Care Med. 2007;22(5):300-9. http://dx.doi.org/10.1177/0885066607304445 PMid:17895488

12. Leigh R, Pizzichini MM, Morris MM, Maltais F, Hargreave FE, Pizzichini E. Stable COPD: predicting benefit from high-dose inhaled corticosteroid treatment. Eur Respir J. 2006;27(5):964-71. PMid:16446316
13. Kanazawa M. Diseases to differentiate from COPD, with emphasis on bronchial asthma [Article in Japanese]. Nihon Rinsho. 2007;65(4):675-81. PMid:17419387

14. Orie NGM, Sluiter HJ, de Vries K.The host factor in bronchitis. In Orie NG, Sluiter HJ, editors. Bronchitis. Assen: Royal van Gorcu; 1961. p. 43-59.

15. James AL, Palmer LJ, Kicic E, Maxwell PS, Lagan SE, Ryan GF, et al. Decline in lung function in the Busselton Health Study: the effects of asthma and cigarette smoking. Am J Respir Crit Care Med. 2005;171(2):109-14. http:// dx.doi.org/10.1164/rccm.200402-2300C PMid:15486340

16. Miravitlles M. Arguments in favor of inhaled corticosteroids in COPD by phenotype instead of by severity. Arch Bronconeumol. 2011;47(6):271-3. http:// dx.doi.org/10.1016/j.arbres.2011.01.016 http://dx.doi. org/10.1016/j.arbr.2011.01.003 PMid:21440355

17. Cruz AA, Carvalho EM. Citologia nasal quantitativa simplificada (CNQS). Rev Bras Alergia e Imunopatol. 1997;20(2):56-8, 63-74.

18. Rufino R, Lapa e Silva JR. Cellular and biochemical bases of chronic obstructive pulmonary disease. J Bras Pneumol. 2006;32(3):241-8. http://dx.doi.org/10.1590/ S1806-37132006000300011 PMid:17273614

19. Neves MC, Peçanha-Martins AC, Veri NF, Santos RS, Cruz AA. Associação entre gravidade de asma brônquica e grau de inflamação nas vias aéreas superiores. J Pneumol.1994;20:S153.

20. Kitaguchi Y, Komatsu Y, Fujimoto K, Hanaoka M, Kubo K. Sputum eosinophilia can predict responsiveness to inhaled corticosteroid treatment in patients with overlap syndrome of COPD and asthma. Int J Chron Obstruct Pulmon Dis. 2012;7:283-9. PMid:22589579 PMCid:3346210

21. Camelier A, Rosa FW, Jones PW, Jardim JR. Brazilian version of airways questionnaire 20: a reproducibility study and correlations in patients with COPD. Respir Med. 2005;99(5):602-8. http://dx.doi.org/10.1016/j. rmed.2004.09.022 PMid:15823458

22. 11 Consenso Brasileiro sobre rinites 2006. Rev Bras Alerg Imunopatol. 2006;29(1):29-58.

23. Souza Junior AS, Hochhegger B, Irion K, Silva IS, Muller NL. Enfisema e Doença Pulmonar Obstrutiva Crônica. In: Muller NL, Silva Cl, editors. Tórax - Série Colégio Brasileiro de Radiologia e Diagnóstico por Imagem. São Paulo: Elsevier; 2011. p. 745-82.

24. Settipane RA, Charnock DR. Epidemiology of rhinitis: allergic and nonallergic. Clin Allergy Immunol. 2007;19:2334. PMid:17153005

25. Rondón C, Campo P, Galindo L, Blanca-López N, Cassinello MS, Rodriguez-Bada JL, et al. Prevalence and clinical relevance of local allergic rhinitis. Allergy. 2012;67(10):1282-8. http://dx.doi.org/10.1111/all.12002 PMid:22913574

26. Solé D, Wandalsen GF, Camelo-Nunes IC, Naspitz CK; ISAAC - Brazilian Group. Prevalence of symptoms of asthma, rhinitis, and atopic eczema among Brazilian children and adolescents identified by the International Study of Asthma and Allergies in Childhood (ISAAC) Phase 3. J Pediatr (Rio J). 2006;82(5):341-6.

27. Hardin M, Silverman EK, Barr RG, Hansel NN, Schroeder JD, Make BJ, et al. The clinical features of the overlap between COPD and asthma. Respir Res. 2011;12:127. http:// dx.doi.org/10.1186/1465-9921-12-127 PMid:21951550 PMCid:3204243 
28. Miravitlles M, Morera J. It's time for an aetiologybased definition of chronic obstructive pulmonary disease. Respirology. 2007;12(3):317-9. http://dx.doi. org/10.1111/j.1440-1843.2007.01082.x PMid:17539832

29. Aribandi M, McCoy VA, Bazan C 3rd. Imaging features of invasive and noninvasive fungal sinusitis: a review.
Radiographics. 2007;27(5):1283-96. http://dx.doi. org/10.1148/rg.275065189 PMid:17848691

30. Schafroth Török S, Leuppi JD. Bronchial hyperresponsiveness and exhaled nitric oxide in chronic obstructive pulmonary disease. Swiss Med Wkly. 2007;137(27-28):385-91. PMid:17705099\#

\section{About the authors}

\section{Margarida Célia Lima Costa Neves}

Physician. Department of Pulmonology, Professor Edgard Santos Hospital Complex; and Professor, Universidade Federal da Bahia - UFBA, Federal University of Bahia - School of Medicine, Salvador, Brazil.

\section{Yuri Costa Sarno Neves}

Medical Student. Universidade Federal da Bahia - UFBA, Federal University of Bahia - School of Medicine, Salvador, Brazil.

\section{Carlos Mauricio Cardeal Mendes}

Epidemiologist. Universidade Federal da Bahia - UFBA, Federal University of Bahia - Salvador, Brazil.

\section{Monalisa Nobre Bastos}

Medical Student. Bahia School of Medicine and Public Health, Salvador, Brazil.

\section{Aquiles Assunção Camelier}

Professor. School of Science and Technology and Bahia School of Medicine and Public Health, Salvador, Brazil.

\section{Cleriston Farias Queiroz}

Biologist. Department of Pulmonology, Professor Edgard Santos Hospital Complex, Universidade Federal da Bahia - UFBA, Federal University of Bahia - School of Medicine, Salvador, Brazil.

\section{Bernardo Fonseca Mendoza}

Medical Student. Universidade Federal da Bahia - UFBA, Federal University of Bahia - School of Medicine, Salvador, Brazil.

\section{Antônio Carlos Moreira Lemos}

Head. Department of Pulmonology, Universidade Federal da Bahia - UFBA, Federal University of Bahia - Hospital das Clínicas, Salvador, Brazil.

\section{Argemiro D'Oliveira Junio}

Physician. Universidade Federal da Bahia - UFBA, Federal University of Bahia - School of Medicine, Salvador, Brazil. 